\title{
CURRENT SITUATION IN ESTONIA ON PACKAGING MANAGEMENT
}

Regio Lehtla

Georemest Ltd.

Estonia

\section{ESTONIAN NATIONAL LEGISLATION ON PACKAGES}

Act on packages, May, 1995

MAIN TASKS:

- to encourage packages reuse or recycling;

- to eliminate possible harmful influence of packages to human beings and environment;

- to diminish generation of packaging waste;

- to harmonise demands on packages and its reuse with international standards.

FINAL PURPOSE:

- at latest in June $200160 \%$ of total amount of packaging material must be reused or recycled;

- not more than $35 \%$ of this amount will be used as material.

These demands comply with the EU Directive 94/62/EC on packages.

\section{REUSING METHODS:}

1. using of the packages on their original shape and purpose (refilling);

2. using of the packages on their original shape but for other purposes;

3. using of the packaging material as secondary raw material for producing packages or other products;

4. using of the packaging material as fuel;

5. using of the organic fraction of the packages by biological treatment (either aerobic or anaerobic treatment). 

BASIS OF THE ACT ON PACKAGES:

- act on excise tax, which will be applied to the non-returnable packages;

- restrictions and special demands on materials, which are used for production of packages;

- order of issuing certificate on the lack of possible dangerous influence of packaging material on human health;

- regulation on packages pant;

- regulation on packages register;

- regulation on Eco-labelling of environmentally sound goods and packages;

- standard on packages labelling;

- state programme on fulfilling the Act on Packages, including normatives on packages reuse demands by different kind of packaging materials.

\section{Act on packaging excise December, 1996}

Packaging waste is one of the main household waste streams, rapidly rising by quantities in Estonia currently. Aim of the act was encourage companies to recycle their packaging material, using economic means (actually it is good example of applying the "PPP" - polluter pays principle in Estonia) and simultaneously obtain some additional financing for other environmental projects (by the Environmental Foundation).

According to this act all enterprises which fill or import the filled packages of alcoholic or non-alcoholic beverages are supposed to pay packaging excise tax. Under the taxation belongs:

1. packages of alcoholic beverages since March, 1997;

2. packages of non-alcoholic (including mineral water and juices) beverages since December, 1998.

\section{Excise tax}

Tax, to be applied, depends of two factors:

1. packaging material and

2. volume of the package 
Table 1: Excise tax per one package unit in EEK

\begin{tabular}{|c|c|c|c|}
\hline & MATERIALS & PER ITEM & PER LITRE \\
\hline 1. & Glass and ceramics & 0,50 & 2,00 \\
\hline 2. & Plastic & 1,00 & 2,00 \\
\hline 3. & Metal & 0,75 & 2,00 \\
\hline 4. & Other & 025 & 1,00 \\
\hline
\end{tabular}

Tax per one package is calculated in such a way, that those two qualitative values are summarised. According to this principle ex. gr. excise tax for one glass bottle (which is not recycled) is EEK 1,5 and per one plastic bottle (volume 2 L) EEK 5 .

But there is a legal way to get disengagement from paying tax:

1. until December 1998, if enterprise reuse or recycle at least $40 \%$ of packages or packaging material;

2. since 1999, if reusing/recycling rate is at least $\mathbf{6 0 \%}$;

3. exported packages.

According to the Packaging Excise Act enterprises can get disengagement from paying the excise tax in advance. As basis for not to pay excise tax serves a certificate, issued by the Ministry of Environment. The order of issuing these certificates and its form are determined by three ministerial Regulations (February, 1997):

1. Order of the determination of the material of the packages;

2. List of documents, needed to get certificate, testifying about the reuse/recycling of the packages/packaging material;

3. Form of the certificate, testifying about the reuse/recycling of the packages/packaging material.

Tax from imported packages is collected immediately on the border by Custom Office, local producers are supposed to pay tax quarterly to the Tax Office. According to the Excise Act the collected tax will be divided equally (50/50) between State Budget and Environmental Fund (Foundation, used for financing different environmental projects in Estonia).

It was also supposed, that applying of the packaging excise tax will arise new, rather substantial financing source both for the Environmental Fund and State budget. But in reality the situation is a bit different. Actually the procedure to get tax disengagement is rather simple. Enterprise need just to present a bundle of documents to Ministry of Environment, which testifies about their serious intention to start packages or packages material reuse/recycling. List of documents includes some data about the enterprise itself, data about the amounts and material 
of the packages and copies of contracts, which describes the method of reuse or recycling, intended to apply.

But as:

- the excise tax is rather high, if compare with general price level in Estonia;

- there is no penalty set up for non-fulfilling the promised recycling activities and;

- it is actually rather simple to just sign some contracts on buying up of used bottles or popcans;

-- almost nobody likes to pay excise tax and acclaims to the recycling in Estonia now.

\section{AMOUNTS OF PACKAGES}

As currently packaging excise tax is applied only to the packages of beverages, I will concentrate only on beverage's packages in further.

By official statistical data on production, export and import of beverages in/to and from Estonia in 1996, then the calculated amounts of packages are following:

Table 2:Amounts of produced, exported and imported beverages in Estonia 1996

\begin{tabular}{|c||c|c|c|c|c|c|c|c|c||}
\hline $\begin{array}{c}\text { Bever- } \\
\text { age }\end{array}$ & $\begin{array}{c}\text { Prod-d. } \\
\text { in Est. } \\
\text { M 1 }\end{array}$ & $\begin{array}{c}\text { Export } \\
\text { M l }\end{array}$ & $\begin{array}{c}\text { Import } \\
\text { M 1 }\end{array}$ & $\begin{array}{c}\text { Balance } \\
\text { M 1 }\end{array}$ & $\begin{array}{c}\text { Esto- } \\
\text { nian \% }\end{array}$ & $\begin{array}{c}\text { Left } \\
\text { M l-s }\end{array}$ & $\begin{array}{c}\text { Main } \\
\text { Pack. }\end{array}$ & $\begin{array}{c}\text { Pack-s } \\
\text { M of } \\
\text { pieces }\end{array}$ & $\begin{array}{c}\text { Calcu- } \\
\text { lated } \\
100 \% \\
\text { Excise } \\
\text { M EEK }\end{array}$ \\
\hline Str. Alc. & 21 & 1,2 & 3,3 & +2.1 & $91 \%$ & 23 & 0,51 & 46 & 69 \\
\hline Wine & 2,1 & 0,4 & 6,7 & +6.4 & $25 \%$ & 8.5 & 0,71 & 12.1 & 23 \\
\hline Beer & 45,4 & 2,0 & 6,1 & +4.1 & $92 \%$ & 49.5 & 0,51 & 99.0 & 148.5 \\
\hline $\begin{array}{c}\text { Alc. To- } \\
\text { tal }\end{array}$ & 87,5 & 3,6 & 16,1 & +12.5 & & 100 & & 157.0 & 240.5 \\
\hline \hline $\begin{array}{c}\text { Soft } \\
\text { drinks }\end{array}$ & 57,1 & 33,2 & 14,1 & -19.1 & $151 \%$ & 37.9 & 0,71 & 54.2 & 103 \\
\hline $\begin{array}{c}\text { Min. wa- } \\
\text { ter }\end{array}$ & 3,9 & 0,6 & 2,0 & +1.4 & $\mathbf{7 4 \%}$ & 5.3 & 0,51 & 10.7 & 16.1 \\
\hline Juice & 4,0 & $?$ & $?$ & $?$ & $?$ & 4 & 11 & 4 & 5 \\
\hline Soft total & 65,0 & & & -17.7 & & 47.2 & & 68.9 & 124.1 \\
\hline TOTAL & $\mathbf{1 5 2 , 5}$ & & & $-\mathbf{5 . 2}$ & & $\mathbf{1 4 7 . 2}$ & & $\mathbf{2 2 6}$ & $\mathbf{3 6 4 . 6}$ \\
\hline
\end{tabular}


The table suggest of following four aspects:

1. Wine is mainly imported to Estonia (75\%).

2. Export of soft drinks exceeds import mainly because of the large Coca-Cola factory in Tallinn, which supplies all three Baltic states.

3. Total tumover of alcoholic beverages is twice over the turnover of soft drinks.

4. If to take into the account typical volume of packages for different drinks, hypothetical annual amount of all beverage's packages is around 365 million EEK, part of alcoholic beverages consist of it approximately $2 / 3-240$ million EEK.

These indirect values have found affirmation afterwards. In March, 1997 the issuing of Excise disengagement certificates (EDC's) was started in the Ministry of Environment (MoE) according to the Act, ministerial regulations and applications, presented by the alcoholic drinks producing or importing companies. As mentioned already earlier, the applying for EDC became soon enormously popular - mainly because that:

1. there is no sanctions established against applicants, if afterwards will be clarified, that applicant did not succeeded to fulfil required recycling rate and

2. it is comparatively easy to apply for EDC. Actually in most cases it needs nothing special, but just to sign contract with some fim, buying up empty bottles.

There is no preference given to reuse or recycling of packages/packages material - these are equal against the law in this case. Reuse is applicable only in the case of glass packages (glass bottles). Main method of reuse is naturally buying up the bottles, cleaning and refilling. Main recycling methods, applicable in Estonia nowadays are following:

1. Buying up glass bottles and selling these into the glass factories (currently there are operating two glass industries in Estonia) as secondary raw material;

2. Buying up metal popcans and exporting them for recycling;

3. Burning the combustible (plastic, wood, paper) packaging material - needs special approval for every case.

Totally there are currently more than one hundred of companies (exact number is still unknown), dealing with alcohol import in Estonia. Domestic alcoholic drink producers are counted - there are 19 enterprises (6 beer breweries, 6 wine manufacturers and 7 strong alcoholic drink producers) dealing with alcohol production in Estonia.

If to compare different materials by the hypothetical excise rates (taking into the consideration most usual packages, made of observed material), which are calculated over in terms of material, then we will get the following succession row: 
1. The most expensive is naturally PET - plastic $/ 1 /$, as it is very light and also packages, made of PET, are usually larger. So, if company does not recycle it's PET plastic, it is supposed to pay EEK 135,000 per non-recycled ton of PET material. It is estimated, that average weigh of one PET - bottle is 37 grams.

2. The second position is held by aluminium $/ 2-3 /$, used for making of popcans. As there is no aluminium industry in Estonia all metallic cans are collected and exported abroad (t. ex. to Sweden) for recycling. Aluminium, as valuable material is profitable to collect even without packaging excise tax.. Approximate price for buying up of scrap-aluminium is around EEK 6,000. Companies are supposed to pay for non-recycled ton of aluminium EEK 88-92,000 (depends of the volume of the popcan) perton. Weigh of the aluminium popcans varies from $16-19$ grams.

3. Twice cheaper is iron /4-5/. Weights of iron made popcans, varies from 26 to 30 grams, also iron has not so high cost in buying up. Ton of non-recycled iron will cost EEK 47-48,000 for enterprise.

4. Glass $/ 6,7,9 /$ is the main category and largest fraction of packaging waste. Rates varying, as glass-bottles may have rather different weights - main fractions are 360 (beer), 500 and 750 (champagne) grams. Price per one nonrecycled ton varies also from EEK 2,700 to 4,200 . Comparable is price for wooden $/ 8 /$ barrels $(3,800)$.

Division of the Estonian packaging market between different packaging materials can be seen from the next slide:

More than $97 \%$ of total volume consist glass bottles. $2 \%$ are metal barrels, which does not represent actual environmental problem.

Approximate annual amounts in mass units:

1. Glass 49,400 tons (more than $13 \mathrm{M}$ pieces);

2. Metal cans - ca 300 tons (ca 21 M pieces); additionally some 900 tons of barrels;

3. Plastic (PET-bottles) - more than $\mathbf{5 0}$ tons (> 1,3 $\mathrm{M}$ pieces).

\section{A. Glass}

Almost $60 \%$ of the total glass packaging amount in Estonian market belongs to the largest brewery in Estonia - Saku Brewery.

\section{B. Metal}

All metal packages are imported - there is no domestic popcans in Estonia. Also the recycling can take place only in abroad. Special issue are metal barrels, which are usually in continuous reuse and will be sent back after emptying. There is totally ca 40 enterprises, importing metal cans (these are mainly beer cans). 


\section{Plastic}

Plastic is most expensive packaging material but as well most difficult for recycling. Until now there are issued only two EDC-s - one on the basis with Dutch firm which will recycle the PET-bottles and another for combustion in approved conditions. The question of plastic recycling will arise more stringently by the end of next year, as greatest producer in Estonia (and Baltic states) of PETbottles is Coca-Cola factory in Tallinn.

\section{"Excise Disengagement Service"}

Currently (October, 1997) are issued already more than 90 EDCs by MoE, which covers already over $95 \%$ of total amount of alcoholic drinks packages. Accordingly the expected sum of the annual packaging excise tax cannot exceed $10 \mathrm{MeEEK}$ realistically. As it is quite inconvenient for all the alcohol importers to establish their own buying-up and recycling system, the new business idea was discovered by some businessmen and new service branch appeared in Estonian market, which can be called "Excise Disengagement Service". Currently there are operating three firms in this area and the business idea can be described briefly so:

1. We will organise buying up and recycling of the packaging material in extent, which enables you to get Excise disengagement (currently $40 \%$ of the packages mass);

2. You will pay us $30-50 \%$ (this depends of material and company) of the amount, you are otherwise supposed to pay as excise tax.

Usually these service firms do not specialise only to the one type of packaging material, but are eager to start collection of every kind of packaging waste.

As the sums of supposed excise tax, to be paid otherwise, are rather big, the offered service became very popular. If to refer Table 1, obviously the greatest interest group became wine importers. Domestic producers established usually glass recycling system to get EDC. How the Estonian "glass recycling market" has been divided is shown on the next slide:

Rapid changes occurred in Estonian secondary material market after Parliament accepted Packaging Excise Act. Ordinary glass scrap became valuable secondary material as it enables companies to apply for tax disengagement. The only question which remain is aspect of control if real recycling takes place or is it only fictional. Especially complicated is this question in the case of glass re-export as glass factories in abroad do not belong to the control sphere of Estonian MoE.

All metal is bought up and exported by one firm - Estonian Metal Export, which reports to $\mathrm{MoE}$ about amounts of packaging metal, purchased from different firms. 